\title{
Downward Wage Rigidity and Job Mobility*
}

\author{
Thomas Cornelißen and Olaf Hübler**
}

DISCUSSION PAPER NO. 349

October 2006

ISSN: 0949-9962

(Revised version of “Downward wage rigidity and labour mobility”, IZA DP 1523)

\begin{abstract}
Using data from the German Socio-Economic Panel (GSOEP) we study whether being individually affected by downward wage rigidity has an effect on layoffs, quits and intra-firm mobility. Within a structural empirical model we estimate the individual extent of wage rigidity. This is expressed by the wage sweep-up, which measures by how much individual wage growth increases through the effect of downward wage rigidity when compared to a counterfactual labour market with flexible wage setting. We find robust negative effects of wage sweep-up on quits and layoffs and some evidence for a positive association of wage sweep-up and promotion opportunities. This is consistent with a core-periphery view of the labour force, where a core work force is protected from layoffs and wage cuts and at the same time enjoys good promotion opportunities. On the other side a peripheral work force provides a buffer for adjustment and suffers from both flexible wages, more insecure jobs and less internal promotion opportunities.
\end{abstract}

KEYWORDS: wage rigidity, wage sweep-up, quits, layoffs, promotions

JEL-CLASSIFICATION: J31, J63

*Acknowledgements: We would like to thank Knut Gerlach, Steinar Holden, Friedhelm Pfeiffer, the participants of the final conference of the international wage flexibility project as well as three anonymous referees for helpful comments. Financial support by the DFG (project no. HU 368/4) is gratefully acknowledged.

** Institute of Empirical Economics, University of Hannover, Königsworther Platz 1, 30167 Hannover, Germany, email: huebler@ewifo.uni-hannover.de,cornelissen@ewifo.uni-hannover.de 


\section{Introduction}

Wage rigidity seems to be a defining characteristic of labour markets in many countries. Various studies have investigated wage rigidity and come to the conclusion that wages are not entirely flexible. Especially downward wage rigidity is of relevance, as labour market institutions and fairness standards usually define lower bounds for the wage evolution, not upper bounds. Downward wage rigidity is a potential cause of unemployment and it may distort the allocation of jobs within firms.

We study the effect of downward wage rigidity on mobility decisions in the German labour market. Using data from the German Socio-Economic Panel (GSOEP), we investigate whether being individually affected by wage rigidity affects job mobility. The extent to which an individual is affected by wage rigidity is measured within an empirical model that allows us to estimate the counterfactual wage growth that would prevail in the absence of rigidities.

We distinguish two types of downward wage rigidity: nominal and contractual rigidity. In our empirical model downward nominal wage rigidity prevents nominal wage cuts, whereas downward contractual wage rigidity prevents wage growth that falls short of the wage growth stipulated by collective wage agreements.

Both types of wage rigidity can induce real wage rigidity which is likely to affect the allocation of workers to jobs and hence job mobility. The data set we use contains richer information on labour market mobility than the data sets that have been used before to measure wage rigidity with this methodological approach. In particular, our data allow us to identify layoffs, quits and intra-firm mobility, namely promotions and transfers.

The paper proceeds as follows. Section 2 develops the theoretical background including potential causes of downward wage rigidity and consequences with respect to labour market mobility. On this basis, hypotheses are derived. Section 3 presents prior empirical work. Section 4 describes our data. Section 5 develops the econometric model. Section 6 presents results, and section 7 concludes.

\section{Theoretical background}

\subsection{Causes of downward wage rigidity}

Theoretical foundations of downward wage rigidity must explain why wages are less responsive to negative shocks than to positive shocks, or in other words: why there is a lower bound to the rate of change of wages. Important theoretical foundations for the existence of lower bounds to the wage evolution are efficiency wage theory, insider-outsider theory as well as theories of efficient contracting.

Fairness standards and reciprocal behaviour induce employers to consider efficiency wages (Akerlof 1982, Akerlof and Yellen 1988, Fehr and Gächter 2000). In order to assess the fairness of their pay, workers compare their wage to some reference wage. If they feel treated in a fair way they offer a high productivity (or low fluctuation) in exchange. In the opposite case workers reciprocate with a low productivity (or high fluctuation). When the reference wage stays relatively constant over the business cycle, firms are likely to avoid wage cuts because the losses in productivity would more than offset the cost savings. Danthine and Kurmann $(2004,2006)$ show this formally for the two cases where the reference wage is the worker's past wage or the firms unit wage cost.

Insider-outsider theory maintains that insiders have some bargaining power due to labour turnover costs or labour laws (Lindbeck and Snower 2001). Social norms and fairness standards may also raise bargaining power. Insiders who are protected from layoffs by seniority rules and employment protection legislation may withstand 
wage cuts in a recession. This prompts layoffs of workers who are not insiders. In a subsequent boom, insiders bargain for wage increases. This lowers the profitability of firms an they do not re-hire formerly laid off workers to the same extent. Over the business cycle, employment is reduced while wages of the employed insiders rise. Bargaining may be mediated by unions. Individual or collective bargaining power makes wage cuts less frequent and wage freezes or wage rises more frequent than they would be in a counterfactual flexible labour market without bargaining power.

Efficient contracting (MacLeod and Malcomson 1993, Holden 1999) has been proposed as a reason for downward nominal wage rigidity (Holden 2002, Elsby 2005). This strand of the literature emphasises that rational agents may chose to apply a fixed nominal wage contract until either side has a credible threat of disrupting trade, in which case renegotiation takes place. The literature argues that fixing the nominal wage in such a way induces efficient investment into specific capital, because it reduces the uncertainty about whether the other party to the contract might capture the rents of the investment. At fixed nominal wages, inflation leads to decreasing real wages and makes upward renegotiation after a positive productivity shock more likely than downward renegotiation after a negative productivity shock. This implies that zero wage growth is frequent, and that wage cuts are comparatively rare as opposed to wage rises.

Zero wage growth may also be an important lower bound to the wage evolution because of fairness standards. For assessing the fairness of the wage set this year, workers take the wage received last year as an important landmark. Other important landmarks are the rate of inflation or the wage growth rate implemented by collective wage agreements (which itself usually depends strongly on the rate of inflation). In our empirical analysis we model two lower bounds for the wage evolution: zero wage growth and collectively bargained wage growth, because a large fraction of the German work force is covered by collective wage agreements. These agreements are usually fixed in nominal terms. They allow to set wages of covered workers above but not below the agreed standard.

To some extent wage rigidity may be efficient. Employers accept certain lower bounds to the wage evolution, because this enhances morale and productivity, reduces fluctuation or encourages investments in specific capital. However, to some extent wage rigidity may be unilaterally enforced through workers' bargaining power without any enhancements of productivity. Employers are likely to oppose to that type of wage rigidity. Pfeiffer (2003) proposes to speak of efficient wage rigidity and bargaining power wage rigidity in order to distinguish these two types of wage rigidity. Indeed, when asked for the reasons of downward wage rigidity, managers in Germany say that not only efficiency wage considerations but also wage floors from collective bargaining are relevant (Franz and Pfeiffer 2003).

\subsection{The effect of wage rigidity on mobility}

In our empirical analysis, the extent of downward wage rigidity at individual level is captured by the wage sweep-up. It measures the excess wage growth due to rigid wages in comparison to a counterfactual labour market with flexible wages. As the wage-employment relationship is central to the economic analysis of the labour market, it is of specific interest to ask how the extent of excess wage growth affects job mobility decisions. We distinguish between external and internal labour mobility. The former comprises quits and layoffs while the latter contains promotions and intra-firm transfers. In the following discussion we formulate hypotheses about whether wage sweep-up increases or decreases job mobility. In the case of layoffs we present two opposing hypothesis, while for the other types of mobility, we restrict the discussion to one hypothesis, conceding that there can also be arguments for the opposite case. 
In search models, quits occur when the discounted utility stream of an alternative job or activity exceeds the discounted utility stream of the current job after mobility costs have been taken into account (Mortensen 1986). Wages as well as non-wage job characteristics are part of the utility associated with a job. To a worker who cares about wages, a high wage sweep-up is an advantage of his current job, as it secures a high wage level and prevents downward wage adjustments in the case of adverse shocks. Ceteris paribus, a high wage sweep-up should therefore reduce the propensity to quit. If an employee interprets the wage sweep-up as a premium to the individual earnings capacity, we should expect that the duration of his search to find a better paid job lasts longer (Gerlach and Hübler 1992) and this means that the probability to quit decreases. Those workers who are not affected by wage sweep-up do not only tend to quit because they feel that they are paid too low compared to other employees in the firm or compared to their effort level, but they may also do so due to a higher anticipated risk of being laid off (see discussion on wage rigidity and layoffs in the next section).

Hypothesis 1: A higher wage sweep-up reduces the propensity to quit.

\section{Layoffs}

If firms cannot or do not want to cut wages, they need some alternative adjustment mechanism to shocks. Firms may prefer to adjust to negative shocks through layoffs. These do less damage to morale and productivity of the remaining workforce, because the concerned workers exit the firm. Laid off workers suffer and would like to react, but they are no longer in the firm. The threat of layoffs may even increase the productivity of those who stay in the firm (Bewley 1999).

Hypothesis 2a: A higher wage sweep-up increases the risk of being laid off.

However, workers are heterogeneous with respect to their degree of wage sweep-up. Whether or not layoffs are positively associated with wage sweep-up at individual level will depend on whether firms lay off workers among those most affected by wage rigidity, or whether firms lay off other groups of workers. If protecting workers from wage cuts is a motivation and incentive device, it may be targeted towards certain groups of workers who are likely to acquire firm-specific human capital and who have a long-term value to the firm. When being forced to lay off personnel, firms are then unlikely to lay off those workers. They may rather lay off other groups of workers. This implies that workers protected against wage cuts or moderate wage growth by rigid wages benefit at the same time from employment security, while other groups of workers simultaneously suffer from higher earnings volatility and greater employment risks.

The same is true if, in the case of wage sweep-up due to bargaining power, intended layoffs of high wage sweepup workers cannot be realised because of employment protection legislation and labour laws. Those insiders that benefit from wage rigidity may also benefit from labour legislation with respect to layoffs. In Germany, firms have to justify layoffs for economic reasons and they are bound to a social plan that stipulates social criteria in order to assess which employees of the work force are actually laid off.

Both explanations correspond to a core-periphery view of the labour force, where a core work force is at the same time protected from layoffs and from wage cuts, whereas a peripheral work force provides a buffer for adjustment and suffers from both flexible wages and more insecure jobs. The resulting hypothesis is the inverse of hypothesis 2a. 
Hypothesis 2b: A higher wage sweep-up reduces the risk of being laid off.

Another adjustment strategy would be to moderate positive wage growth rates of those workers not directly affected by wage rigidity in order to make up for the excess wage growth of those workers affected. The cost of downward wage adjustments may actually not only reduce wage cuts, but may also make firms more reluctant to grant wage increases, as they know that reversals of wage increases in the future are costly (Elsby 2005). Such a compression of the wage growth distribution would not necessarily reduce employment, although it would distort the allocation of workers of different skills and productivity in comparison with an uncompressed wage growth distribution.

\section{Promotions}

Employers might use positional changes to adjust wages when wages within positions are rigid (Solon, Whatley and Stevens 1997). Wage rises are realised through promotions. Wage freezes or moderate wage growth might be implemented by reducing promotion opportunities or even by increasing demotions or transfers. Workers with a high wage sweep-up are less likely to receive a promotion because wage growth in the past had exceeded productivity growth for these workers. They are less productive per unit of wage costs and further promotions are thus unlikely.

Hypothesis 3: A higher wage sweep-up reduces the chances of being promoted.

\section{Transfers of personnel}

Workers who have accumulated a high wage sweep-up may be transferred to positions where they are more productive relative to their wage level or to positions where wages are less rigid. The old position can then be filled with a worker who can be recruited internally or externally at a lower wage. If the new position exhibits lower or more volatile wage growth, this may also have direct adverse consequences on productivity and therefore it is questionable whether it is a feasible option when efficiency wage considerations are an important factor. A demotion might be as harmful to worker motivation as a wage cut. However, if in the new position efficiency wage considerations are a minor factor (e.g. if output can be monitored more easily or if shirking is less costly) the impact of a transfer on productivity may be less severe than that of a wage cut in the same position. In a setting where wages are rigid primarily due to bargaining power, and thus efficiency wage considerations do not play a role, aspects of motivation are less important. Adverse effects of demotions or transfers on worker productivity are then expected to be small, thus making them a possible strategy to circumvent wage rigidity.

Hypothesis 4: A higher wage sweep-up increases the likelihood of being transferred to a different job within the firm.

\section{Related literature}

The earnings function approach we use to measure wage rigidity is pioneered by Altonji and Devereux (2000) who explore downward rigidity in nominal wages for the U.S. They estimate the probability of receiving a nominal wage cut at close to zero and conclude that nominal wage rigidity is a pervasive phenomenon in the U.S. labour market. The earnings function approach has been applied to measure downward nominal wage 
rigidity in Switzerland (Fehr and Goette 2005), Italy (Devicienti 2002) and Germany (Knoppik and Beissinger 2003) ${ }^{1}$. Downward nominal wage rigidity, which prevents wage cuts, translates into downward real wage rigidity at low rates of inflation ${ }^{2}$. However, downward nominal wage rigidity is not the only reason for downward real wage rigidity, because wages can be rigid at any rate of wage growth. The earnings function approach has therefore been extended by also considering situations where wages cannot be increased by less than a certain rigidity threshold, for example the rate of inflation. When in addition to nominal wage rigidity such a supplementary rigidity threshold is considered, the literature has termed this as modelling 'real wage rigidity', although the threshold is not necessarily always equal to the rate of inflation (Bauer, Bonin and Sunde 2003, Devicienti, Maida and Sestito 2003, Barwell and Schweitzer 2005). Fehr, Goette and Pfeiffer 2002 have equalled the rigidity threshold to the collectively bargained wage growth rate and therefore termed the wage rigidity defined by their model as contractual wage rigidity. The studies that have extended the earnings function approach in such a way find that a higher share of the work force is affected by real or contractual wage rigidity than by nominal wage rigidity, and that wage growth is swept up more substantially by real or contractual wage rigidity than by nominal wage rigidity.

Several studies that have used the earnings function approach to measure wage rigidity also explore whether an effect of wage rigidity on unemployment and mobility can be established. Fehr and Goette (2005), Bauer, Bonin and Sunde (2003) and Devicienti, Maida and Sestito (2003) find positive associations between wage sweep-up and unemployment. They all study the effects at some level of aggregation. In order to see whether wage rigidity distorts job allocations within firms, however, one has to look at the micro level.

At the micro level, Altonji and Devereux (2000) find modest support for the hypothesis that wage sweep-up reduces quits, but their analysis shows no clear effect of wage sweep-up on layoffs and promotions. Pfeiffer (2003), based on the model estimated in Fehr, Goette and Pfeiffer (2002), finds that wage sweep-up decreases the individual unemployment risk and the incidence of external job changes. While the analysis shows no adverse consequences for those workers affected by wage rigidity, a high wage sweep-up seems to be linked to declining employment at the firm level and to attenuated employment growth at the sectoral level. Pfeiffer (2003, p. 266) therefore concludes that wage rigidity does not have adverse effects on those workers directly affected by the rigidity, but on others whose wages are flexible.

To our knowledge our study is the first to include internal transfers into the analysis of the effects of wage rigidity. For Germany, our analysis is the first to include internal job mobility and to distinguish quits and layoffs exactly instead of proxying them by job changes and unemployment spells. A further contribution of the study is methodological. Under the assumption that rounding is an adequate indicator of measurement error we assign the incidence of measurement error at individual level instead of estimating a global parameter of the probability that observations are affected by measurement error as preceding studies have done (see section 5 for details).

\footnotetext{
${ }^{1}$ Of course a number of other methods have been applied to measure wage rigidity by analysing the features of the wage change distribution in micro data sets. See for example Beissinger and Knoppik (2001) and Christofides and Stengos (2002).

${ }^{2}$ We should mention that Kandil's (2005) empirical investigation demonstrates that prices appear more downwardly rigid than nominal wages in response to demand fluctuations in the U.S. Therefore real wage reductions during economic downturns can be exacerbated. However, demand fluctuations are not the only shocks of relevance for wage growth.
} 


\section{The data}

We use data from the German Socio-Economic panel (GSOEP) household survey that contains a rich set of socio-economic variables. Our data cover the period from 1984 - 2004. An overview of the structure of the GSOEP is provided by Haisken-DeNew and Frick (2003).

We restrict our sample to employed workers between 18 and 65 years of age, for whom data on wages is available for at least two consecutive years. Apprentices are excluded. We drop observations where monthly wages are below $250 €$.

The GSOEP states the gross wage including overtime payment, as well as contractual working hours and overtime. The values refer to the month prior to the interview. We construct hourly wages by dividing the monthly gross wage by the sum of monthly contractual hours and overtime. This measures labour costs more appropriately than if only the contractual working hours were considered. Through the variation of overtime work firms may gain some wage flexibility that would not show up in a measure of hourly wages that just accounted for contractual working time.

We capture wage growth by taking the difference in the log wage for all wage observations that are available in two consecutive years. We trim the wage change distribution by dropping observations with absolute wage changes of more than $0.5 \log$ points, thereby removing $4 \%$ of the observations, assuming that such high growth rates are not correctly measured. Besides regressors from the GSOEP, we also match external information to our data set. These are the annual inflation and unemployment rate as well as data on collectively bargained wage growth. The inflation rate is constructed from the consumer price index of the German Federal Statistical Office $^{3}$. Unemployment rates for East and West Germany are published by the German Federal Labour Office ${ }^{4}$. The index of collectively bargained wages is published by the German Federal Statistical Office ${ }^{5}$. The index is not available for all sectors. Notably the agricultural sector is missing, some parts of the public sector are missing, and, apart from the hotel and restaurants industry, large parts of the service sector are missing. This has to be kept in mind when interpreting our results. Furthermore, for East Germany the index is only available from 1995. When constructing collectively bargained wage growth rates a further year is lost. East German observations thus only enter our analysis from 1996 onwards. Missing values of regressors further reduce the sample size $e^{6}$. Finally, from 1984 to 2003 we have 41626 wage change observations.

\footnotetext{
${ }^{3}$ The consumer price index is available on-line in the "prices" section of the German Federal Statistical Office homepage, http://www.destatis.de/themen/e/thm_preise.htm, link accessed on 30 ${ }^{\text {th }}$ September 2004.

${ }^{4}$ Monthly and yearly unemployment data by region is available at the German Federal Labour Office on-line at http://www.pub.arbeitsamt.de/hst/services/statistik/aktuell/iiia4/zr_alo_qu_west_ostb.xls, link accessed on $25^{\text {th }}$ September 2004.

${ }^{5}$ The data is taken from the German Federal Statistical Office. Up to 2002 the data are from the STATIS CD-ROM time series data base, segments 4031, 4033, 4037, 4039, 4055 and 4057. After 2002 they are updated from the GENESIS online data base of the German Federal Statistical Office. In our sample collectively bargained wage growth is on average $3.1 \%$ with a standard deviation of $1.5 \%$ and a maximum of $11.5 \%$.

${ }^{6}$ Compared to the whole sample, our estimation sample contains a higher share of male workers (0.66 as opposed to 0.56) which is mostly due to the under sampling of the public and the service sector. Workers in the estimation sample are on average two years older and have two more years of tenure than workers in the whole sample. The distribution of education, firm size and employment status is not altered much by the sample selection.
} 
The GSOEP survey includes retrospective questions on job mobility. Respondents are asked whether there were any employment changes since the first of January of the preceding year and, if so, which types of changes. We use the response option „I have started a new position with a different employer“ to identify external job mobility and „I have changed positions within the same company“ to identify internal job mobility. External job moves can be further classified through another question that asks how the previous employment relationship was terminated. We use the option „My resignation“ to identify quits and „Dismissal“ to identify layoffs. Internal job moves can be further classified through a question asking respondents to compare their current position with their previous one along several dimensions, including the type of work and the income. In our analysis, promotions qualify as those internal job moves where the worker either states an improved income or an unchanged income alongside improvements in the type of work. We regard the remaining internal moves as demotions or transfers. More details on the job mobility variables are presented in Cornelißen/Hübler (2005, appendix A).

The data set has strengths and weaknesses for the present purpose. The benefit from using household survey data is that available regressors are much richer with respect to socio-economic, demographic and work-place related information. While administrative data may provide very accurately measured data on wages, quite often variables of particular interest are missing. For example, comparing the GSOEP survey to the German IAB employment sub-sample (IABS, Beschäftigtenstichprobe), the GSOEP has more detailed information on hours worked, human capital and job mobility. In fact, the IABS lacks information on hours worked. Only the broad categories full- and part-time are reported, and changes between the two within a given year are not registered. Furthermore, earnings data are right censored, as wages are only recorded up to the social security contribution ceiling. This reduces some of the alleged accuracy of the IABS. Job changes and job separations can be identified in the IABS, but the reason for the separation is unknown. In the GSOEP, we can identify quits, layoffs and other separations separately, as well as internal job moves at the same employer. Job mobility being in the focus of our analysis means we would not be able to conduct our analysis with the IABS.

However, by using a household survey as opposed to administrative data we have to cope with two drawbacks. Firstly, household surveys usually provide smaller sample sizes than data sets that are provided by the social security or fiscal administration. Secondly, household surveys are more prone to measurement error than registry data from official sources. This makes the estimation of wage growth rates, that takes place within the structural model presented in the next section, less precise, although it is possible to take measurement error into account when formulating the model.

\section{The econometric model and estimation issues}

We estimate the extent of wage rigidity using the earnings function approach introduced by Altonji and Devereux (2000). This approach models the observed wage change through

(i) an underlying notional wage change that is the wage change which would prevail in absence of wage rigidity,

(ii) the effect of downward wage rigidity, and

(iii) the effect of measurement error.

The model we use is similar to the one devised by Dickens and Goette (2002), which represents a generalisation of the original Altonji-Devereux model in that it incorporates not only downward nominal wage rigidity but it 
adds another wage setting regime. As in Fehr, Goette and Pfeiffer (2003), we add a contractually rigid wage setting regime and we use data on collectively bargained wage growth as the rigidity threshold in this regime.

The notional wage change $w_{i t}^{*}$ for individual $i$ at time $t$ depends on a set of covariates $x_{i t}$,

$$
w_{i t}^{*}=x_{i t}^{\prime} \beta+e_{i t} \quad e_{i t} \sim N\left(0, \sigma_{e}^{2}\right) \text {, }
$$

where $\beta$ is a coefficient vector and $e_{i t}$ the error term.

Whether or not an individual actually receives her notional wage change depends on whether the wage is set in a rigid wage setting regime, and whether wage setting within this regime is constrained or not. There are three wage setting regimes, a flexible, a nominally rigid regime and a contractually rigid regime.

In the flexible wage setting regime, the actual wage change of the worker, $w_{i t}^{a}$, always equals the notional wage change

$w_{i t}^{a}=x_{i t}^{\prime} \beta+e_{i t}$.

In the two rigid regimes, the actual wage changes equals the notional wage change only if the notional wage change exceeds a certain threshold value.

Formally, wage setting in the nominally rigid regime is then characterised by

$$
\begin{aligned}
w_{i t}^{a} & =x_{i t}^{\prime} \beta+e_{i t} & & \text { if } x_{i t}^{\prime} \beta+e_{i t}>0 \\
& =0 & & \text { otherwise }
\end{aligned}
$$

and in the contractually rigid regime by

$$
\begin{aligned}
w_{i t}^{a} & =x_{i t}^{\prime} \beta+e_{i t} & & \text { if } x_{i t}^{\prime} \beta+e_{i t}>r_{i t} \\
& =r_{i t} & & \text { otherwise }
\end{aligned}
$$

The rigid regimes are tobit models with left censoring of the distribution the respective rigidity threshold. The variable $r_{i t}$ is provided as data in the form of the collectively bargained wage growth. Providing the rigidity threshold as data gives more structure to the estimation and reduces the parameter space. Equalling it to the collectively bargained wage growth takes account of the fact that in Germany a large share of employees is covered by collective bargaining agreements.

The observed wage change is likely to differ from the notional wage change not only because of wage rigidity, but also because of measurement error (misreporting), a problem that is likely to be prevalent in the data set. The observed wage change, $w_{i t}^{o}$, is then the actual wage, $w_{i t}^{a}$, change plus measurement error, $m_{i t}$ :

$w_{i t}^{o}=w_{i t}^{a}+m_{i t} \quad m_{i t} \sim N\left(0, \sigma_{m}\right)$

We assume that $m_{i t}$ is independent of $e_{i t}$.

With the measurement error term added to all observations, the three regimes in terms of the observed wage growth become:

$w_{i t}^{0}=x_{i t}^{\prime} \beta+e_{i t}+m_{i t}$

for the flexible wage setting regime, 


$$
\begin{aligned}
w_{i t}^{o} & =x_{i t}^{\prime} \beta+e_{i t}+m_{i t} & & \text { if } x_{i t}^{\prime} \beta+e_{i t}>0 \\
& =m_{i t} & & \text { otherwise }
\end{aligned}
$$

for the nominally rigid regime, and

$$
\begin{aligned}
w_{i t}^{o} & =x_{i t}^{\prime} \beta+e_{i t}+m_{i t} & & \text { if } x_{i t}^{\prime} \beta+e_{i t}>r_{i t} \\
& =r_{i t}+m_{i t} & & \text { otherwise }
\end{aligned}
$$

for the contractually rigid regime.

We model a restricted measurement error (Model 1). Instead of adding a measurement error term uniformly to all observations, this is done only for individuals that have reported a rounded value of the wage level in either of two consecutive periods, while treating individuals that have not rounded their wage levels in any of two consecutive periods as error free (i.e. according to equations (2)-(4)). With this definition $92.9 \%$ of the observations fall into the measurement error regime, the remaining $7.1 \%$ into the regime without measurement error. Under the assumption that rounding is an adequate indicator of measurement error this procedure has the advantage of assigning the measurement error regime at individual level instead of estimating a global parameter of the probability that observations are affected by measurement error. Supplementary, we also estimate a model under the assumption of uniform measurement error (Model 2).

In order to complete the models, we have to account for the individual propensities, $p^{C}, p^{N}$ and $p^{F}$, of falling into the contractually rigid, nominally rigid and flexible regime respectively. These parameters are made dependent on explanatory variables. We estimate the relative propensities $p^{C} / p^{F}$, and $p^{N} / p^{F}$ as

$\frac{p_{i t}^{C}}{p_{i t}^{F}}=\exp \left(z_{i t}^{\prime} \lambda\right)$

and

$\frac{p_{i t}^{N}}{p_{i t}^{F}}=\exp \left(z_{i t}^{\prime} \varpi\right)$,

where $z_{i t}$ is a vector of explanatory variables, $\lambda$ and $\varpi$ are the corresponding coefficient vectors. Once the relative propensities are estimated, the absolute propensities $p^{C}, p^{F}$ and $p^{N}$ can be recovered, as (9), (10) and $p^{C}+p^{N}+p^{F}=1$ form a system of three linear equations in three unknowns.

The model parameters $\beta, \gamma, \lambda$, $\varpi$, as well as the standard deviations of the error terms, can be estimated simultaneously by maximum likelihood.

Once notional wage growth and the other model parameters are estimated, we can determine expected actual wage growth as well as the wage sweep-up, which is the difference between expected actual wage growth and notional wage growth

$s u_{i t}=E\left[w_{i t}^{a}-w_{i t}^{*}\right]$.

The subsequent analysis of mobility effects consists of heteroskedastic probit regressions of quits, layoffs, promotions and transfers on the wage sweep-up and other control variables. Let $y_{i t}$ be a binary outcome variable that takes on the value 1 if job mobility of individual $i$ takes place at time $t$, and the value 0 if no job mobility takes place. We apply a multiplicative heteroskedastic probit model, where the expected probability of a job mobility event is 


$$
\mathrm{P}\left(y_{i t}=1\right)=\Phi\left\{\frac{x_{i t}^{\prime} \beta}{\exp \left(z_{i t}^{\prime} \gamma\right)}\right\},
$$

where $x_{i t}$ and $z_{i t}$ are vectors of covariates influencing respectively the mean and standard deviation of the latent variable underlying the probit model, $\beta$ and $\gamma$ are the related coefficient vectors, and $\Phi(\cdot)$ is the standard normal cumulative distribution function. Estimated coefficients cannot be readily interpreted as marginal effects. For regressors $w_{k}$ that are elements of both, $x$ and $z$, marginal effects of $w_{k}$ on $P\left(y_{i t}=1\right)$ depend on $\beta_{k}$ and $\gamma_{k}$ as well as on the linear combinations $x^{\prime} \beta$ and $z^{\prime} \gamma$ (Greene 2003, p. 680):

$$
\frac{\partial \operatorname{Prob}(Y=1 \mid x, z)}{\partial w_{k}}=\phi\left[\frac{x^{\prime} \beta}{\exp \left(z^{\prime} \gamma\right)}\right] \frac{\beta_{k}-\left(x^{\prime} \beta\right) \cdot \gamma_{k}}{\exp \left(z^{\prime} \gamma\right)} \text {. }
$$

Throughout the analysis of the heteroskedastic probit model, we report marginal effects at means. We derive the respective standard errors needed for inference using the delta method (Davidson / MacKinnon 2004, pp.202208).

\section{Results}

\subsection{Estimates of the wage rigidity model}

Tables

Table 1 reports the maximum likelihood estimation results of the wage rigidity model 1 with restricted measurement error. As a robustness check the estimation under the assumption of uniform measurement error is presented in Appendix A1. We report robust standard errors as well as standard errors adjusted for clustering on the year of observation in order to take into account biased estimates of standard errors due to heteroskedasticity and within-group correlation of the error term. The latter may pose a problem in our estimation, as we have matched the unemployment and inflation rates at year level, a procedure which magnifies the bias from within group correlation if such correlation is present (Moulton 1990).

\section{[Insert Table 1 about here]}

The coefficients of the notional wage growth equation displayed in panel A of Tables

Table 1 are in line with expectations. The panels B and C of the table report the coefficients of the regime propensity equations. The regime propensities are estimated as non-linear transformations (see equations 9 and 10). Therefore, the coefficients cannot be interpreted as marginal effects, but their signs and significance can be assessed.

A positive coefficient on nominal GDP growth for both regime propensities indicates that wage rigidity seems to react cyclically. In upturns, the extent of rigidity rises and in downturns it falls. Firms seem to have more scope to restrain wage growth in recessionary periods. Firms that voluntarily set wages according to collective bargaining agreements may refrain from doing so. Firms covered by union agreements can also moderate the growth of effective wages if they reduce pay components that are not mandatory under the collective contract and thus reduce the 'effective coverage'. With respect to the propensity of the nominal rigid regime, the manufacturing sector seems not to differ from the rest of the economy. The coefficient on the manufacturing dummy is not statistically different from zero. However, the propensity of the contractual regime is significantly 
lower in manufacturing as compared to the rest of the economy. This can be explained by the important weight of the public sector which dominates the reference group and which is a sector with high union coverage 7 .

\section{Panel D of Tables}

Table 1 reports summary statistics for the wage rigidity model. Observed wage growth over the whole period is around $4.1 \%$. The wage growth predicted by the model is $4.3 \%$ on average. This is decomposed into a notional wage growth of 0.9 and a wage sweep-up of $3.4 \%$. At individual level the wage sweep-up varies between 1.4 and $6.5 \%$. An estimated $45 \%$ of the work force are in the contractually rigid wage setting regime, $2 \%$ in the nominally rigid regime, and for $53 \%$ wage setting is flexible ${ }^{8}$.

Model 2 presented in Appendix A1 predicts a lower notional wage growth of $-0.8 \%$ and a correspondingly higher wage sweep-up of $4.9 \%$ on average. An estimated $32 \%$ of the work force are in the contractually rigid wage setting regime, $28 \%$ in the nominal rigid regime, and for $40 \%$ wage setting is flexible.

Clearly, the way that measurement error is modelled has an effect on the estimated extent of wage rigidity. Although the extent of wage sweep-up differs between the two models, the signs and significance of the determinants in the two models are mostly similar. The wage sweep-ups estimated from the two models are correlated with a highly significant correlation coefficient of 0.96 .

In essence our results match those of Pfeiffer (2003) in that there is a non negligible extent of wage sweep-up, which is predominantly due to contractual rigidities, and at the same time wage setting is flexible for more than half of the work force. That similar results can be found on the basis of different datasets underlines the robustness of the existence of wage rigidities in the German labour market.

Our results of the extent of wage rigidity are very robust over a range of different specifications of the regime propensities (not reported here), such as the inclusion of the regional unemployment rate, dummies for East German and male workers as well as additional sector dummies, individual tenure and schooling into the regime propensity equations. Even though the extent of wage rigidity was robust, we obtained coefficients on some dummies of a very high magnitude ( $>3$ ). This may well be due to the fact that some cells are too sparsely populated. Therefore, and in the vein of a parsimonious specification, we opted for the present model. The results also carry over when the wage rigidity model is estimated in a sample of over 25 year-olds.

\subsection{The effects of wage rigidity on mobility}

In the following analysis, heteroskedastic probit regressions of quits, layoffs, promotions and transfers are presented, where the wage sweep-up and other controls are included as regressors. The timing is such that mobility events between $t$ and $t+1$ are explained by labour market regressors at time $t$. The wage sweep-up at time $t$, which enters the mobility equations, is based on the wage change observation between $t-1$ and $t$. In all mobility regressions, the heteroskedasticity equation is specified equally and includes key determinants of job mobility, namely the wage sweep-up, the wage level and the number of past external job moves. Tables $2-5$

\footnotetext{
${ }^{7}$ In a different specification where we replaced the manufacturing dummy by a public sector dummy, contractual wage rigidity was significantly higher in the public sector than in the reference group.

${ }^{8}$ In a linear regression of the wage sweep-up on worker characteristics and time and sector dummies we find that ceteris paribus wage sweep-up is positively related to nominal GDP growth, that it is higher in East Germany and higher for foreigners, men, high wage workers, more tenured workers, less educated workers and workers in smaller firms (which can be explained by lower notional wage growth in smaller firms).
} 
report the results in terms of marginal effects at means of the regressors on the probability of the mobility events. For those variables that are part of the heteroskedasticity equation, the marginal effect at means can vary in sign. This is due to the functional form of the marginal effects under heteroskedasticity shown in equation (13). In the case of the wage sweep-up we therefore also report the fraction of individuals in the sample that display a positive marginal effect of the wage sweep-up.

For each mobility event we estimate four different specifications. Specification (1) is the baseline model which includes the hourly wage level besides the wage sweep-up and a set of control variables. Specification (2) adds the regressors age and age squared. Specification (3) replaces the absolute wage level by the residual of a wage equation ("wage gap"). This is a measure of the individual wage relative to the wage that one would expect given the observable individual characteristics. Such a relative wage measure may be more important for mobility decisions than the absolute wage level, especially in the case of quits.

The wage sweep-up is a complex non-linear interaction of collectively bargained wage growth and of notional wage growth. It is therefore warranted to control for both of these factors in order to isolate the effect of wage rigidity. While many individual characteristics that determine notional wage growth are already included in the control variables, collectively bargained wage growth is not. Specification (4), our preferred specification, therefore adds collectively bargained wage growth as a control variable. ${ }^{9}$ All four specifications include the wage sweep-up estimated by model 1 . The results can be replicated with the wage sweep-up of model 2 , as both wage sweep-ups are nearly perfectly correlated. Appendix A2 presents the results for specification (4) when the wage sweep-up of model 2 is used.

\section{Quits}

Table 2 reports the probit regression of the quit decision on the wage sweep-up and control variables. The marginal effect at means of the wage sweep-up on the probability to quit is negative and highly significant in all specifications. This suggests that a high wage sweep-up reduces the propensity to quit, as stated in our hypothesis 1 . The marginal effect at means is negative for all individuals in the sample. The estimated effects suggest that for an average individual an increase in the wage sweep-up of one percentage point, say from $3 \%$ to $4 \%$, reduces the propensity to quit by between 0.54 and 1.56 percentage points. This is a quite sizeable effect if compared to the sample probability of a quit of $3.26 \%$. This is in line with the results of Altonji and Devereux (2000) who find support for the hypothesis that a higher wage sweep-up reduces the propensity to quit.

The wage level has no significant effect on quits, but the wage gap reduces the propensity to quit significantly. This implies that not the wage level per se influences quitting but the wage level relative to the wage one can expect given relevant labour market characteristics. Collectively bargained wage growth increases quitting. This may be because favourable collectively bargained wage growth in a given industry indicates good labour market conditions, which in turn encourages job changes. Controlling for this effect increases the negative effect of wage sweep-up on quits. The coefficients of the control variables are in line with expectations.

[Insert Table 2 about here]

\footnotetext{
${ }^{9}$ We thank the anonymous referees for suggesting to include a relative wage measure and collectively bargained wage growth into the mobility equations.
} 


\section{Layoffs}

Table 3 reports probit regressions of layoff decisions on the wage sweep-up and control variables. The marginal effect at means of the wage sweep-up on the probability of a layoff is not significant in the baseline specification (1). However, when including age as a regressor in specification (2), the effect of the wage sweep-up on layoffs becomes negative and significant. The wage level significantly reduces layoffs, but the wage gap does not (specification (3)). Specification (4) suggests that the risk of layoffs rises with collectively bargained wage growth. However, layoffs then seem to concern low wage sweep-up workers more than high wage sweep-up workers (and low wage workers more than high wage workers). This finding confirms hypothesis 2b. Individuals with a high wage sweep-up are less likely to be laid off. The marginal effects at means across specifications suggest that an increase in the wage sweep-up of one percentage point reduces the propensity of being laid off by between 0.48 and 1.61 percentage points, which is quite sizeable relative to the sample probability of a layoff of $2.98 \%$. The marginal effect is negative not only for an average individual, but for virtually all individuals in the sample. In the specifications where the effect is significant, at most $2 \%$ of the individuals in the sample have a positive predicted marginal effect of the wage sweep-up on layoffs. The coefficients of the control variables are in line with expectations.

[Insert Table 3 about here]

For those sectors included in our analysis, the negative association between wage sweep-up and layoffs is obtained holding sectors constant. Therefore we suppose that it is not due to segregation across sectors, but that it prevails within sectors. However, we can say nothing on whether the negative association is valid within firms, or whether there is segregation across firms.

Our results match the findings of Pfeiffer (2003, p. 255ff) that workers with a higher wage sweep-up do not face an increased risk of unemployment and that they have a reduced probability of changing the establishment within the following year.

\section{Promotions}

Table 4 reports probit regressions of promotions on the wage sweep-up and control variables. The marginal effect at means of the wage sweep-up on the probability of being promoted is negative and significant in specification (1). Once age is controlled for, the effect of the wage sweep-up becomes insignificant (specifications (2) and (3)). When controlling additionally for collectively bargained wage growth, which is the case in specification (4), the effect of the wage sweep-up on promotions becomes positive and significant and suggests that an increase of the wage sweep-up of one percentage point increases the probability of promotions by 0.34 percentage points. The coefficients of the control variables are in line with expectations.

\section{[Insert Table 4 about here]}

The result that wage sweep-up increases promotion opportunities is the opposite of what we have expected (hypothesis 3). An explanation for this results could be that promotion tournaments, which can be understood as incentive devices (Lazear and Rosen 1981) are a complementary personnel policy to efficiency wages. Both, promotion opportunities and wage rigidity might be combined in order to set incentives and motivate workers. 


\section{Transfers}

Table 5 reports probit regressions of transfers on the wage sweep-up and control variables. As in the case of promotions, the effect of wage sweep-up on transfers is negative and significant in specification (1). Once age is controlled for, the effect becomes positive. However, it stays insignificant across the specifications (2) to (4).

Therefore we cannot confirm our hypothesis 4 that transfers are more likely for high wage sweep-up workers.

\section{[Insert Table 5 about here]}

Demotions or transfers might be too damaging to morale and therefore not be an adequate means to cope with rigid wages.

\section{Conclusion}

Using data from the German Socio-Economic Panel (GSOEP), we have analysed the extent of contractual and nominal downward wage rigidity as well as its effect on labour mobility in Germany over the period of 19852004.

Within a structural empirical model of wage rigidity, we have estimated that downward wage rigidity increases wage growth by between 3.4 and 4.9 percentage points in the aggregate each year in comparison to a counterfactual labour market with flexible wage setting. We have exploited the variation of this wage sweep-up at individual level in order to estimate probit equations to measure its effect on layoffs, quits, promotions and internal transfers of personnel. According to our results, the effect of the wage sweep-up on quits and layoffs is negative, highly significant and robust across specifications. Wage sweep-up has a strong stabilizing effect on employment relations. The negative association with quits suggests that wage sweep-up constitutes a job specific net advantage. The negative association with layoffs suggests that in the parts of the economy represented by our data there is a dual labour market: A core work force is at the same time protected from layoffs and from wage cuts, whereas a peripheral work force suffers from both, flexible wages and more insecure jobs and provides a

buffer for adjustment. However, on the basis of these results for external mobility we cannot discriminate between two concurring explanations: (i) employers aiming at motivating the core work force and tying it to the firm by preventing it from wage cuts and layoffs, or (ii) the core work force being endowed with bargaining power to avoid wage cuts and simultaneously being protected from layoffs by labour legislation or norms.

According to our results for internal job mobility, wage sweep-up seems to go in hand with increased promotion opportunities and there seem to be no effects on transfers and demotions. The duality in the labour market seems to be even stronger than was visible by only considering external mobility. Not only are high wage sweep-up workers protected form layoffs but they also seem to enjoy better promotion opportunities than their low wage sweep-up counterparts. One explanation might be that internal systems of promotions are complementary to efficiency wages. This suggests that the duality in the labour market is to an important extent driven by incentive and motivation considerations and not simply by bargaining power.

We see several perspectives of future research that could extend the present analysis. The model of wage rigidity could be extended by also incorporating symmetric rigidity such as menu costs. Furthermore, it would be worthwhile to implement a model of downward wage rigidity into a data set that allows international comparison, such as the European Community Household Panel (ECHP) an thus to contribute to the empirical literature that has carried out international comparisons in the present field of research (Holden and Wulfsberg 2005, Knoppik and Beissinger 2005, Behr and Pötter 2005). Finally, a model of downward wage rigidity should 
be implemented in a linked-employer-employee data set, which would allow to model the labour demand side much more extensively by including numerous firm characteristics into the analysis. 


\section{References}

Akerlof GA (1982) Labor contracts as partial gift exchange. Quarterly Journal of Economics 97:543-569

Akerlof GA, Yellen JL (1988) Fairness and unemployment. American Economic Review, Papers and Proceedings 78:44-49

Altonji JG, Devereux PJ (2000) The extent and consequences of downward nominal wage rigidity. Research in Labor Economics 19:383-431

Barwell RD, Schweitzer ME (2005) The incidence of nominal and real wage rigidities in Great Britain: 19871998. Federal Reserve Bank of Cleveland Working Paper 05-08

Bauer T, Bonin H, Sunde U (2003) Real and nominal wage rigidities and the rate of inflation: Evidence from German micro data. IZA Discussion Paper 959

Behr A, Pötter U (2005) Downward wage rigidity in europe: A new flexible parametric approach and empirical results. CAWM Discussion Paper 14

Beissinger T, Knoppik C (2001) Downward nominal rigidity in West-German earnings 1975-1995. German Economic Review 2:385-417

Bewley T (1999) Why wages don’t fall during a recession. Harvard University Press, Cambridge

Christofides LN, Stengos T (2002) The symmetry of the wage-change distribution: Survey and contract data. Empirical Economics 27:705-723

Cornelißen T, Hübler O (2005) Downward wage rigidity and labour mobility. IZA Discussion Paper 1523, Bonn

Danthine JP, Kurmann A (2004) Fair wages in a new Keynesian model of the business cycle. Review of Economic Dynamics 7:107-142

Danthine JP, Kurmann A (2006) Efficiency wages revisited: The internal reference perspective. Economics Letters 90:278-284

Davidson R, MacKinnon JG (2004) Econometric theory and methods. Oxford University Press, New York

Devicienti F (2002) Downward nominal wage rigidity in Italy: Evidence and consequences. Lavoro e relazioni industriali 2002/2:125-180

Devicienti F, Maida A, Sestito P (2003) Nominal and real wage rigidity: An assessment using Italian microdata. LABORatorio Riccardo Revelli Working Paper 33

Dickens W, Goette L (2002) Notes on estimating rigidity using an analytic likelihood function. mimeo

Elsby MWL (2005) Evaluating the economic significance of downward nominal wage rigidity. CEP Discussion Paper 704

Fehr E, Gächter S (2000) Fairness and retaliation: The economics of reciprocity. Journal of Economic Perspectives 14:159-181 
Fehr E, Goette L (2005) Robustness and real consequences of nominal wage rigidity. Journal of Monetary Economics 52:779-804

Fehr E, Goette L, Pfeiffer F (2002) Dimensions and consequences of wage rigidities in Germany. ZEW and University of Zurich, mimeo

Franz W, Pfeiffer F (2003) Zur ökonomischen Rationalität von Lohnrigiditäten aus Sicht von Unternehmen, Jahrbücher für Nationalökonomie und Statistik 223:23-57

Gerlach K, Hübler O (1992) Zuschläge zum Lohnpotential und individuelle Arbeitslosigkeit. In: Franz W (ed.) Mikro- und makroökonomische Aspekte der Arbeitslosigkeit. Beiträge zur Arbeitsmarkt- und Berufsforschung 166, pp. 146-174

Greene W (2003) Econometric Analysis. Prentice Hall, New Jersey

Haisken-DeNew JP, Frick JR (2003) Desktop companion to the German Socio-Economic Panel study. DIW, Berlin

Holden S (1999) Renegotiation and the efficiency of investments. Rand Journal of Economics 30:106-119

Holden S (2002) Downward nominal wage rigidity - contracts or fairness considerations? mimeo

Holden S, Wulfsberg F (2005) Downward nominal wage rigidity in the OECD. Memorandum 10/2005, Department of Economics, University of Oslo

Kandil M (2005) Countercyclical or procyclical real wages? A disaggregate explanation of aggregate asymmetry. Empirical Economics 30:619-642

Knoppik C, Beissinger T (2003) How rigid are nominal wages? Evidence and implications for Germany. Scandinavian Journal of Economics 105:643-659

Knoppik C, Beissinger T (2005) Downward nominal wage rigidity in Europe: An analysis of European micro data from the ECHP 1994-2001. IZA Discussion Paper 1492, Bonn

Lazear EP, Rosen S (1981) Rank-order tournaments as optimum labor contracts. Journal of Political Economy 89:841-864

Lindbeck A, Snower DJ (2001) Insiders versus outsiders. Journal of Economic Perspectives 15:165-188

MacLeod WB, Malcomson JM (1993) Investments, holdup, and the form of market contracts. American Economic Review 83:811-837

Mortensen DT (1986) Job search an labor market analysis. In: Ashenfelter O, Layard R (eds.) Handbook of labor economics Vol. II. North-Holland, Amsterdam, pp. 849-919

Moulton BR (1990) An illustration of a pitfall in estimating the effects of aggregate variables on microdata. The Review of Economics and Statistics 72:334-338 
Pfeiffer F (2003) Lohnrigiditäten im gemischten Lohnbildungssystem. ZEW Wirtschaftsanalysen Band 65, Nomos, Baden-Baden

Solon G, Whatley W, Stevens AH (1997) Wage changes and intrafirm job mobility over the business cycle: Two case studies. Industrial and Labor Relations Review 50:402-415 


\section{Tables}

Table 1: Estimation results of the wage rigidity model with restricted measurement errors (Model 1)

\begin{tabular}{|c|c|c|c|c|c|c|c|}
\hline \multicolumn{4}{|c|}{ A) Notional Wage change } & \multicolumn{4}{|c|}{$\begin{array}{l}\text { B) Relative propensity of nominally } \\
\text { rigid regime [log }(\mathrm{pn} / \mathrm{pf})]\end{array}$} \\
\hline & Coeff. $^{\text {a) }}$ & \multicolumn{2}{|c|}{ p-val. ${ }^{\text {b) }}$} & & Coeff. & \multicolumn{2}{|c|}{ p-val. ${ }^{\text {b) }}$} \\
\hline & & & (ii) & & & & (ii) \\
\hline male & -0.45 & 0.03 & 0.01 & nominal GDP growth & 0.56 & 0.00 & 0.00 \\
\hline foreign & -0.28 & 0.34 & 0.49 & manufacturing & 0.94 & 0.20 & 0.39 \\
\hline schooling & -0.08 & 0.16 & 0.09 & constant & -6.66 & 0.00 & 0.00 \\
\hline tenure & -0.24 & 0.00 & 0.00 & & & & \\
\hline tenure squared / 100 & 0.51 & 0.00 & 0.00 & \multirow{2}{*}{\multicolumn{4}{|c|}{$\begin{array}{l}\text { C) Relative propensity of contractually } \\
\text { rigid regime [log }(\mathrm{pn} / \mathrm{pf})]\end{array}$}} \\
\hline experience & -0.32 & 0.00 & 0.00 & & & & \\
\hline experience squared / 100 & 0.45 & 0.00 & 0.00 & & \multicolumn{3}{|c|}{ p-val. ${ }^{\text {b) }}$} \\
\hline months unempl. last year & -0.17 & 0.50 & 0.55 & & Coeff. & (i) & (ii) \\
\hline firm size $>=20<200$ & 0.80 & 0.01 & 0.01 & nominal GDP growth & 0.03 & 0.00 & 0.32 \\
\hline firm size $>=200<2000$ & 1.26 & 0.00 & 0.00 & manufacturing & -0.30 & 0.00 & 0.00 \\
\hline firm size $>2000$ & 1.71 & 0.00 & 0.00 & constant & -0.21 & 0.00 & 0.06 \\
\hline intermediate status group & 0.36 & 0.16 & 0.19 & & & & \\
\hline high status group & 1.49 & 0.00 & 0.00 & \multicolumn{4}{|c|}{ D) Summary statistics } \\
\hline skill training last period & 1.23 & 0.05 & 0.06 & (4) & & & \\
\hline East Germany & 0.85 & 0.29 & 0.22 & & & & \\
\hline South Germany & -0.24 & 0.23 & 0.32 & \multicolumn{4}{|l|}{ Wage growth (means) } \\
\hline education parents & -0.04 & 0.66 & 0.70 & observed & 0.041 & & \\
\hline Diff. Unempl. Rate, t & -0.93 & 0.31 & 0.40 & predicted & 0.043 & & \\
\hline Diff. Unempl. Rate, t-1 & 0.38 & 0.36 & 0.36 & notional & 0.009 & & \\
\hline Diff. Unempl. Rate, t-2 & -1.31 & 0.03 & 0.16 & & & & \\
\hline inflation & -0.79 & 0.34 & 0.43 & \multicolumn{4}{|l|}{ Wage sweep-up } \\
\hline inflation, $\mathrm{t}-1$ & 1.36 & 0.00 & 0.00 & mean & 0.034 & & \\
\hline inflation, t-2 & -0.40 & 0.52 & 0.08 & standard deviation & 0.007 & & \\
\hline mining & -0.50 & 0.43 & 0.51 & $5^{\text {th }}$ percentile & 0.023 & & \\
\hline manufacturing & 0.62 & 0.06 & 0.11 & $10^{\text {th }}$ percentile & 0.025 & & \\
\hline ressource processing & 0.09 & 0.82 & 0.79 & $25^{\text {th }}$ percentile & 0.029 & & \\
\hline transp. \& communication & -0.39 & 0.38 & 0.19 & $50^{\text {th }}$ percentile & 0.034 & & \\
\hline building sector & -0.31 & 0.43 & 0.45 & $75^{\text {th }}$ percentile & 0.039 & & \\
\hline services & 0.45 & 0.72 & 0.75 & $90^{\text {th }}$ percentile & 0.044 & & \\
\hline credit and insurance & -0.01 & 0.99 & 0.98 & $95^{\text {th }}$ percentile & 0.047 & & \\
\hline public utilities & 0.00 & 0.99 & 0.99 & minimum & 0.014 & & \\
\hline year 1988 & 2.98 & 0.18 & 0.12 & maximum & 0.065 & & \\
\hline year 1989 & 0.10 & 0.98 & 0.98 & & & & \\
\hline year 1990 & -0.39 & 0.89 & 0.90 & \multicolumn{4}{|c|}{ Regime propensities (means) } \\
\hline year 1991 & -0.45 & 0.91 & 0.93 & $p^{C}$ & 0.45 & & \\
\hline year 1992 & 2.76 & 0.49 & 0.57 & $p^{N}$ & 0.02 & & \\
\hline year 1993 & 0.30 & 0.92 & 0.93 & $p^{F}$ & 0.53 & & \\
\hline year 1994 & -1.89 & 0.13 & 0.20 & & & & \\
\hline year 1996 & 3.11 & 0.00 & 0.00 & \multicolumn{4}{|l|}{ Standard errors } \\
\hline year 1997 & -0.75 & 0.63 & 0.60 & $\sigma_{\mathrm{e}}$ & 0.156 & & \\
\hline year 1998 & -3.22 & 0.02 & 0.00 & $\sigma_{\mathrm{m}}$ & 0.052 & & \\
\hline year 1999 & -0.60 & 0.41 & 0.21 & & & & \\
\hline year 2000 & -0.47 & 0.84 & 0.86 & & & & \\
\hline year 2001 & -2.60 & 0.31 & 0.35 & No. of observations & 41626 & & \\
\hline year 2002 & -1.31 & 0.43 & 0.47 & Log likelihood & 23006.2 & & \\
\hline year 2003 & 0.41 & 0.67 & 0.64 & & & & \\
\hline constant & 6.59 & 0.00 & 0.00 & & & & \\
\hline
\end{tabular}

a) All coefficients in panel $A$ are multiplied by 100 .

b) $p$-values are based on

(i) robust "Huber/White/sandwich" standard errors,

(ii) standard errors adjusted for within group error term correlation, clustering on year. 
Table 2: Heteroskedastic probit regression of quits in period $t+1$

\begin{tabular}{|c|c|c|c|c|c|c|c|c|}
\hline & \multicolumn{2}{|c|}{ (1) } & \multicolumn{2}{|l|}{ (2) } & \multicolumn{2}{|l|}{ (3) } & \multicolumn{2}{|l|}{ (4) } \\
\hline No. of observations & \multicolumn{2}{|c|}{38328} & \multicolumn{2}{|c|}{38328} & \multicolumn{2}{|c|}{38328} & \multicolumn{2}{|c|}{38328} \\
\hline P-Val. Wald test of joint significance ${ }^{1)}$ & \multicolumn{2}{|c|}{0} & \multicolumn{2}{|c|}{0} & \multicolumn{2}{|l|}{0} & \multicolumn{2}{|c|}{0} \\
\hline P-Val. LR test of heteroskedasticity ${ }^{2)}$ & \multicolumn{2}{|c|}{0} & \multicolumn{2}{|l|}{0} & \multicolumn{2}{|l|}{0} & \multicolumn{2}{|c|}{0} \\
\hline Sample probability of $y=1$ & \multicolumn{2}{|c|}{$3.26 \%$} & \multicolumn{2}{|c|}{$3.26 \%$} & \multicolumn{2}{|c|}{$3.26 \%$} & \multicolumn{2}{|c|}{$3.26 \%$} \\
\hline Mean predicted probability of $y=1$ & \multicolumn{2}{|c|}{$3.26 \%$} & \multicolumn{2}{|c|}{$3.26 \%$} & \multicolumn{2}{|c|}{$3.26 \%$} & \multicolumn{2}{|c|}{$3.26 \%$} \\
\hline Probability of $\mathrm{y}=1$ predicted at means & \multicolumn{2}{|c|}{$1.48 \%$} & \multicolumn{2}{|c|}{$1.42 \%$} & \multicolumn{2}{|c|}{$1.42 \%$} & \multicolumn{2}{|c|}{$1.46 \%$} \\
\hline & $\begin{array}{c}\mathrm{dP} / \mathrm{dX} \text { at } \\
\text { means }\end{array}$ & P-Val & $\begin{array}{l}\mathrm{dP} / \mathrm{dX} \text { at } \\
\text { means }\end{array}$ & P-Val & $\begin{array}{c}\mathrm{dP} / \mathrm{dX} \text { at } \\
\text { means }\end{array}$ & $\begin{array}{l}\text { P- } \\
\text { Val }\end{array}$ & $\begin{array}{l}\mathrm{dP} / \mathrm{dX} \text { at } \\
\text { means }\end{array}$ & $\begin{array}{l}\text { P- } \\
\text { Val }\end{array}$ \\
\hline wage sweep-up * 100 & $-1.06 \%$ & 0.00 & $-0.54 \%$ & 0.05 & $-0.58 \%$ & 0.04 & $-1.56 \%$ & 0.00 \\
\hline hourly wage level & $-0.001 \%$ & 0.93 & $0.001 \%$ & 0.97 & - & - & $0.001 \%$ & 0.96 \\
\hline wage gap (earnings equation residual) & - & - & - & - & $-0.12 \%$ & 0.00 & - & - \\
\hline collectively bargained wage growth & - & - & - & - & - & - & $0.34 \%$ & 0.01 \\
\hline age & - & - & $0.03 \%$ & 0.51 & $-0.02 \%$ & 0.63 & $0.15 \%$ & 0.02 \\
\hline age squared & - & - & $-0.001 \%$ & 0.15 & $-0.0002 \%$ & 0.69 & $-0.002 \%$ & 0.01 \\
\hline fulltime & $-0.46 \%$ & 0.03 & $-0.50 \%$ & 0.02 & $-0.54 \%$ & 0.01 & $-0.54 \%$ & 0.02 \\
\hline East Germany & $-0.84 \%$ & 0.00 & $-0.84 \%$ & 0.00 & $-0.48 \%$ & 0.00 & $-0.89 \%$ & 0.00 \\
\hline foreign & $-0.40 \%$ & 0.00 & $-0.43 \%$ & 0.00 & $-0.45 \%$ & 0.00 & $-0.36 \%$ & 0.00 \\
\hline male & $0.35 \%$ & 0.00 & $0.28 \%$ & 0.02 & $0.10 \%$ & 0.41 & $0.39 \%$ & 0.00 \\
\hline schooling & $0.09 \%$ & 0.00 & $0.09 \%$ & 0.00 & $0.01 \%$ & 0.64 & $0.07 \%$ & 0.02 \\
\hline number skill trainings & $0.06 \%$ & 0.43 & $0.05 \%$ & 0.50 & $0.03 \%$ & 0.68 & $0.01 \%$ & 0.88 \\
\hline tenure & $-0.15 \%$ & 0.00 & $-0.14 \%$ & 0.00 & $-0.16 \%$ & 0.00 & $-0.12 \%$ & 0.00 \\
\hline firm size $>=20<200$ & $-0.70 \%$ & 0.00 & $-0.58 \%$ & 0.00 & $-0.69 \%$ & 0.00 & $-0.77 \%$ & 0.00 \\
\hline firm size $>=200<2000$ & $-0.94 \%$ & 0.00 & $-0.79 \%$ & 0.00 & $-0.94 \%$ & 0.00 & $-1.06 \%$ & 0.00 \\
\hline firm size $>2000$ & $-1.38 \%$ & 0.00 & $-1.19 \%$ & 0.00 & $-1.41 \%$ & 0.00 & $-1.56 \%$ & 0.00 \\
\hline number external moves & $-0.01 \%$ & 0.93 & $-0.01 \%$ & 0.85 & $-0.04 \%$ & 0.62 & $-0.001 \%$ & 1.00 \\
\hline public sector & $-0.93 \%$ & 0.00 & $-0.90 \%$ & 0.00 & $-0.89 \%$ & 0.00 & $-0.92 \%$ & 0.00 \\
\hline intermediate status group & $-0.09 \%$ & 0.49 & $-0.08 \%$ & 0.53 & $-0.23 \%$ & 0.07 & $-0.18 \%$ & 0.18 \\
\hline high status group & $-0.44 \%$ & 0.02 & $-0.27 \%$ & 0.17 & $-0.80 \%$ & 0.00 & $-0.59 \%$ & 0.01 \\
\hline Fraction with $\mathrm{dP} / \mathrm{d}$ (sweep-up) $>0$ & 0.0 & & 0.00 & & 0.00 & & 0.00 & \\
\hline
\end{tabular}

All equations include time and sector dummies.

1) $\mathrm{H}_{0}$ : "coefficients jointly insignificant"

2) $\mathrm{H}_{0}$ : "homoskedasticity" (The heteroskedasticity equation contains the regressors wage level, wage sweep-up, and number of external job moves.) 
Table 3: Heteroskedastic probit regression of layoffs in period $t+1$

\begin{tabular}{|c|c|c|c|c|c|c|c|c|}
\hline & \multicolumn{2}{|c|}{$(1)$} & \multicolumn{2}{|l|}{$(2)$} & \multicolumn{2}{|l|}{ (3) } & \multicolumn{2}{|l|}{ (4) } \\
\hline No. of observations & \multicolumn{2}{|c|}{38328} & \multicolumn{2}{|c|}{38328} & \multicolumn{2}{|c|}{38328} & \multicolumn{2}{|c|}{38328} \\
\hline P-Val. Wald test of joint significance ${ }^{1)}$ & \multicolumn{2}{|c|}{0} & \multicolumn{2}{|c|}{0} & \multicolumn{2}{|c|}{0} & \multicolumn{2}{|c|}{0} \\
\hline P-Val. LR test of heteroskedasticity ${ }^{2)}$ & \multicolumn{2}{|c|}{0.40} & \multicolumn{2}{|l|}{0.10} & \multicolumn{2}{|l|}{0.07} & \multicolumn{2}{|l|}{0.01} \\
\hline Sample probability of $y=1$ & \multicolumn{2}{|c|}{$2.98 \%$} & \multicolumn{2}{|c|}{$2.98 \%$} & \multicolumn{2}{|c|}{$2.98 \%$} & \multicolumn{2}{|c|}{$2.98 \%$} \\
\hline Mean predicted probability of $y=1$ & \multicolumn{2}{|c|}{$2.98 \%$} & \multicolumn{2}{|c|}{$2.98 \%$} & \multicolumn{2}{|c|}{$2.98 \%$} & \multicolumn{2}{|c|}{$2.98 \%$} \\
\hline Probability of $\mathrm{y}=1$ predicted at means & \multicolumn{2}{|c|}{$1.69 \%$} & \multicolumn{2}{|c|}{$1.64 \%$} & \multicolumn{2}{|c|}{$1.64 \%$} & \multicolumn{2}{|c|}{$1.60 \%$} \\
\hline & $\begin{array}{c}\mathrm{dP} / \mathrm{dX} \text { at } \\
\text { means }\end{array}$ & P-Val & $\begin{array}{l}\mathrm{dP} / \mathrm{dX} \text { at } \\
\text { means }\end{array}$ & P-Val & $\begin{array}{l}\mathrm{dP} / \mathrm{dX} \text { at } \\
\text { means }\end{array}$ & $\begin{array}{l}\text { P- } \\
\text { Val }\end{array}$ & $\begin{array}{l}\mathrm{dP} / \mathrm{dX} \text { at } \\
\text { means }\end{array}$ & $\begin{array}{l}\text { P- } \\
\text { Val }\end{array}$ \\
\hline wage sweep-up * 100 & $-0.21 \%$ & 0.25 & $-0.48 \%$ & 0.04 & $-0.50 \%$ & 0.03 & $-1.61 \%$ & 0.00 \\
\hline hourly wage level & $-0.11 \%$ & 0.00 & $-0.10 \%$ & 0.00 & - & - & $-0.10 \%$ & 0.00 \\
\hline wage gap (earnings equation residual) & - & - & - & - & $-0.03 \%$ & 0.57 & - & - \\
\hline collectively bargained wage growth & - & - & - & - & - & - & $0.42 \%$ & 0.00 \\
\hline age & - & - & $-0.17 \%$ & 0.00 & $-0.18 \%$ & 0.00 & $-0.01 \%$ & 0.94 \\
\hline age squared & - & - & $0.003 \%$ & 0.00 & $0.003 \%$ & 0.00 & $0.001 \%$ & 0.16 \\
\hline fulltime & $-0.03 \%$ & 0.89 & $0.06 \%$ & 0.80 & $0.05 \%$ & 0.80 & $0.06 \%$ & 0.79 \\
\hline East Germany & $1.44 \%$ & 0.00 & $1.51 \%$ & 0.00 & $1.76 \%$ & 0.00 & $1.26 \%$ & 0.00 \\
\hline foreign & $0.56 \%$ & 0.00 & $0.58 \%$ & 0.00 & $0.57 \%$ & 0.00 & $0.70 \%$ & 0.00 \\
\hline male & $0.21 \%$ & 0.15 & $0.22 \%$ & 0.12 & $0.17 \%$ & 0.30 & $0.34 \%$ & 0.01 \\
\hline schooling & $-0.05 \%$ & 0.14 & $-0.04 \%$ & 0.25 & $-0.06 \%$ & 0.21 & $-0.06 \%$ & 0.09 \\
\hline number skill trainings & $-0.13 \%$ & 0.20 & $-0.08 \%$ & 0.40 & $-0.09 \%$ & 0.35 & $-0.12 \%$ & 0.22 \\
\hline tenure & $-0.03 \%$ & 0.02 & $-0.05 \%$ & 0.00 & $-0.05 \%$ & 0.00 & $-0.03 \%$ & 0.02 \\
\hline firm size $>=20<200$ & $-0.64 \%$ & 0.00 & $-0.71 \%$ & 0.00 & $-0.75 \%$ & 0.00 & $-0.89 \%$ & 0.00 \\
\hline firm size $>=200<2000$ & $-1.10 \%$ & 0.00 & $-1.15 \%$ & 0.00 & $-1.20 \%$ & 0.00 & $-1.38 \%$ & 0.00 \\
\hline firm size > 2000 & $-1.48 \%$ & 0.00 & $-1.50 \%$ & 0.00 & $-1.57 \%$ & 0.00 & $-1.82 \%$ & 0.00 \\
\hline number external moves & $0.23 \%$ & 0.00 & $0.23 \%$ & 0.00 & $0.22 \%$ & 0.00 & $0.19 \%$ & 0.01 \\
\hline public sector & $-1.26 \%$ & 0.00 & $-1.26 \%$ & 0.00 & $-1.26 \%$ & 0.00 & $-1.21 \%$ & 0.00 \\
\hline intermediate status group & $-0.46 \%$ & 0.00 & $-0.43 \%$ & 0.01 & $-0.48 \%$ & 0.00 & $-0.52 \%$ & 0.00 \\
\hline high status group & $-0.12 \%$ & 0.64 & $-0.26 \%$ & 0.26 & $-0.44 \%$ & 0.21 & $-0.63 \%$ & 0.00 \\
\hline Fraction with $\mathrm{dP} / \mathrm{d}$ (sweep-up) $>0$ & \multicolumn{2}{|c|}{0.14} & \multicolumn{2}{|l|}{0.02} & 0.02 & & 0.00 & \\
\hline
\end{tabular}

All equations include time and sector dummies.

1) $\mathrm{H}_{0}$ : "coefficients jointly insignificant"

2) $\mathrm{H}_{0}$ : "homoskedasticity" (The heteroskedasticity equation contains the regressors wage level, wage sweep-up, and number of external job moves.) 
Table 4: Heteroskedastic probit regression of promotions in period $t+1$

\begin{tabular}{|c|c|c|c|c|c|c|c|c|}
\hline & \multicolumn{2}{|c|}{ (1) } & \multicolumn{2}{|l|}{ (2) } & \multicolumn{2}{|l|}{ (3) } & \multicolumn{2}{|l|}{ (4) } \\
\hline No. of observations & \multicolumn{2}{|c|}{36764} & \multicolumn{2}{|c|}{36764} & \multicolumn{2}{|c|}{36764} & \multicolumn{2}{|c|}{36764} \\
\hline P-Val. Wald test of joint significance ${ }^{1)}$ & \multicolumn{2}{|c|}{0} & \multicolumn{2}{|c|}{0} & \multicolumn{2}{|c|}{0} & \multicolumn{2}{|c|}{0} \\
\hline P-Val. LR test of heteroskedasticity ${ }^{2)}$ & \multicolumn{2}{|c|}{0} & \multicolumn{2}{|l|}{0} & \multicolumn{2}{|l|}{0.003} & \multicolumn{2}{|c|}{0.001} \\
\hline Sample probability of $y=1$ & \multicolumn{2}{|c|}{$1.38 \%$} & \multicolumn{2}{|c|}{$1.38 \%$} & \multicolumn{2}{|c|}{$1.38 \%$} & \multicolumn{2}{|c|}{$1.38 \%$} \\
\hline Mean predicted probability of $y=1$ & \multicolumn{2}{|c|}{$1.37 \%$} & \multicolumn{2}{|c|}{$1.38 \%$} & \multicolumn{2}{|c|}{$1.38 \%$} & \multicolumn{2}{|c|}{$1.38 \%$} \\
\hline \multirow[t]{2}{*}{ Probability of $y=1$ predicted at means } & \multicolumn{2}{|c|}{$0.68 \%$} & \multicolumn{2}{|c|}{$0.56 \%$} & \multicolumn{2}{|c|}{$0.56 \%$} & \multicolumn{2}{|c|}{$0.55 \%$} \\
\hline & $\begin{array}{c}\mathrm{dP} / \mathrm{dX} \text { at } \\
\text { means }\end{array}$ & P-Val & $\begin{array}{l}\mathrm{dP} / \mathrm{dX} \text { at } \\
\text { means }\end{array}$ & P-Val & $\begin{array}{l}\mathrm{dP} / \mathrm{dX} \text { at } \\
\text { means }\end{array}$ & $\begin{array}{l}\text { P- } \\
\text { Val }\end{array}$ & $\begin{array}{l}\mathrm{dP} / \mathrm{dX} \text { at } \\
\text { means }\end{array}$ & $\begin{array}{l}\text { P- } \\
\text { Val }\end{array}$ \\
\hline wage sweep-up * 100 & $-0.55 \%$ & 0.00 & $0.13 \%$ & 0.24 & $0.13 \%$ & 0.24 & $0.34 \%$ & 0.02 \\
\hline hourly wage level & $-0.02 \%$ & 0.06 & $-0.02 \%$ & 0.06 & - & - & $-0.02 \%$ & 0.07 \\
\hline wage gap (earnings equation residual) & - & - & - & - & $-0.007 \%$ & 0.79 & - & - \\
\hline collectively bargained wage growth & - & - & - & - & - & - & $-0.10 \%$ & 0.05 \\
\hline age & - & - & $-0.06 \%$ & 0.00 & $-0.06 \%$ & 0.00 & $-0.06 \%$ & 0.00 \\
\hline fulltime & $0.22 \%$ & 0.09 & $0.10 \%$ & 0.46 & $0.09 \%$ & 0.47 & $0.11 \%$ & 0.39 \\
\hline East Germany & $0.02 \%$ & 0.86 & $-0.07 \%$ & 0.54 & $-0.04 \%$ & 0.82 & $-0.02 \%$ & 0.85 \\
\hline foreign & $-0.29 \%$ & 0.00 & $-0.28 \%$ & 0.00 & $-0.28 \%$ & 0.00 & $-0.29 \%$ & 0.00 \\
\hline male & $0.07 \%$ & 0.41 & $-0.01 \%$ & 0.89 & $-0.02 \%$ & 0.83 & $-0.04 \%$ & 0.61 \\
\hline schooling & $0.09 \%$ & 0.00 & $0.10 \%$ & 0.00 & $0.10 \%$ & 0.00 & $0.10 \%$ & 0.00 \\
\hline number skill trainings & $0.29 \%$ & 0.00 & $0.22 \%$ & 0.00 & $0.23 \%$ & 0.00 & $0.22 \%$ & 0.00 \\
\hline tenure & $0.01 \%$ & 0.20 & $0.02 \%$ & 0.00 & $0.02 \%$ & 0.00 & $0.02 \%$ & 0.01 \\
\hline firm size $>=20<200$ & $0.30 \%$ & 0.18 & $0.47 \%$ & 0.04 & $0.45 \%$ & 0.06 & $0.52 \%$ & 0.03 \\
\hline firm size $>=200<2000$ & $1.12 \%$ & 0.00 & $1.41 \%$ & 0.00 & $1.37 \%$ & 0.00 & $1.51 \%$ & 0.00 \\
\hline firm size $>2000$ & $1.57 \%$ & 0.00 & $1.89 \%$ & 0.00 & $1.84 \%$ & 0.00 & $2.06 \%$ & 0.00 \\
\hline number external moves & $0.13 \%$ & 0.00 & $0.16 \%$ & 0.00 & $0.15 \%$ & 0.00 & $0.15 \%$ & 0.00 \\
\hline public sector & $0.16 \%$ & 0.32 & $0.11 \%$ & 0.40 & $0.11 \%$ & 0.41 & $0.11 \%$ & 0.41 \\
\hline intermediate status group & $0.15 \%$ & 0.13 & $0.12 \%$ & 0.19 & $0.10 \%$ & 0.30 & $0.13 \%$ & 0.13 \\
\hline high status group & $0.24 \%$ & 0.21 & $0.52 \%$ & 0.02 & $0.46 \%$ & 0.16 & $0.64 \%$ & 0.01 \\
\hline Fraction with $\mathrm{dP} / \mathrm{d}$ (sweep-up) $>0$ & \multicolumn{2}{|c|}{0.00} & \multicolumn{2}{|l|}{0.92} & 0.90 & & 1.00 & \\
\hline
\end{tabular}

All equations include time and sector dummies.

1) $\mathrm{H}_{0}$ : "coefficients jointly insignificant"

2) $\mathrm{H}_{0}$ : "homoskedasticity" (The heteroskedasticity equation contains the regressors wage level, wage sweep-up, and number of external job moves.) 
Table 5: Heteroskedastic probit regression of transfers in period $t+1$

\begin{tabular}{|c|c|c|c|c|c|c|c|c|}
\hline & \multicolumn{2}{|c|}{$(1)$} & \multicolumn{2}{|l|}{$(2)$} & \multicolumn{2}{|l|}{ (3) } & \multicolumn{2}{|l|}{ (4) } \\
\hline No. of observations & \multicolumn{2}{|c|}{36764} & \multicolumn{2}{|c|}{36764} & \multicolumn{2}{|c|}{36764} & \multicolumn{2}{|c|}{36764} \\
\hline P-Val. Wald test of joint significance ${ }^{1)}$ & \multicolumn{2}{|c|}{0} & \multicolumn{2}{|c|}{0} & \multicolumn{2}{|c|}{0} & \multicolumn{2}{|c|}{0.001} \\
\hline P-Val. LR test of heteroskedasticity ${ }^{2)}$ & \multicolumn{2}{|c|}{0.07} & \multicolumn{2}{|l|}{0.20} & \multicolumn{2}{|l|}{0.07} & \multicolumn{2}{|c|}{0.13} \\
\hline Sample probability of $y=1$ & \multicolumn{2}{|c|}{$0.66 \%$} & \multicolumn{2}{|c|}{$0.66 \%$} & \multicolumn{2}{|c|}{$0.66 \%$} & \multicolumn{2}{|c|}{$0.66 \%$} \\
\hline Mean predicted probability of $y=1$ & \multicolumn{2}{|c|}{$0.66 \%$} & \multicolumn{2}{|c|}{$0.66 \%$} & \multicolumn{2}{|c|}{$0.66 \%$} & \multicolumn{2}{|c|}{$0.66 \%$} \\
\hline Probability of $y=1$ predicted at means & \multicolumn{2}{|c|}{$0.38 \%$} & \multicolumn{2}{|c|}{$0.36 \%$} & \multicolumn{2}{|c|}{$0.36 \%$} & \multicolumn{2}{|c|}{$0.36 \%$} \\
\hline & $\begin{array}{l}\mathrm{dP} / \mathrm{dX} \text { at } \\
\text { means }\end{array}$ & P-Val & $\begin{array}{l}\mathrm{dP} / \mathrm{dX} \text { at } \\
\text { means }\end{array}$ & P-Val & $\begin{array}{l}\mathrm{dP} / \mathrm{dX} \text { at } \\
\text { means }\end{array}$ & $\begin{array}{l}\text { P- } \\
\text { Val }\end{array}$ & $\begin{array}{l}\mathrm{dP} / \mathrm{dX} \text { at } \\
\text { means }\end{array}$ & $\begin{array}{l}\text { P- } \\
\text { Val }\end{array}$ \\
\hline wage sweep-up * 100 & $-0.17 \%$ & 0.03 & $0.03 \%$ & 0.73 & $0.01 \%$ & 0.92 & $0.19 \%$ & 0.11 \\
\hline hourly wage level & $0.01 \%$ & 0.11 & $0.01 \%$ & 0.08 & - & - & $0.01 \%$ & 0.10 \\
\hline wage gap (earnings equation residual) & - & - & - & - & $-0.026 \%$ & 0.33 & - & - \\
\hline collectively bargained wage growth & - & - & - & - & - & - & $-0.08 \%$ & 0.07 \\
\hline age & - & - & $-0.02 \%$ & 0.00 & $-0.02 \%$ & 0.00 & $-0.02 \%$ & 0.00 \\
\hline fulltime & $0.16 \%$ & 0.05 & $0.13 \%$ & 0.12 & $0.12 \%$ & 0.16 & $0.14 \%$ & 0.10 \\
\hline East Germany & $0.13 \%$ & 0.24 & $0.10 \%$ & 0.37 & $0.22 \%$ & 0.25 & $0.14 \%$ & 0.22 \\
\hline foreign & $0.01 \%$ & 0.90 & $-0.0001 \%$ & 1.00 & $-0.01 \%$ & 0.95 & $-0.01 \%$ & 0.87 \\
\hline male & $-0.12 \%$ & 0.09 & $-0.15 \%$ & 0.04 & $-0.18 \%$ & 0.02 & $-0.17 \%$ & 0.02 \\
\hline schooling & $0.06 \%$ & 0.00 & $0.06 \%$ & 0.00 & $0.05 \%$ & 0.03 & $0.06 \%$ & 0.00 \\
\hline number skill trainings & $0.11 \%$ & 0.00 & $0.10 \%$ & 0.00 & $0.10 \%$ & 0.00 & $0.10 \%$ & 0.00 \\
\hline tenure & $0.01 \%$ & 0.16 & $0.01 \%$ & 0.03 & $0.01 \%$ & 0.14 & $0.01 \%$ & 0.13 \\
\hline firm size $>=20<200$ & $-0.001 \%$ & 0.99 & $0.04 \%$ & 0.79 & $0.00 \%$ & 0.98 & $0.07 \%$ & 0.62 \\
\hline firm size $>=200<2000$ & $0.19 \%$ & 0.21 & $0.25 \%$ & 0.12 & $0.19 \%$ & 0.24 & $0.31 \%$ & 0.07 \\
\hline firm size $>2000$ & $0.61 \%$ & 0.00 & $0.69 \%$ & 0.00 & $0.58 \%$ & 0.01 & $0.79 \%$ & 0.00 \\
\hline number external moves & $0.05 \%$ & 0.04 & $0.06 \%$ & 0.01 & $0.05 \%$ & 0.03 & $0.06 \%$ & 0.01 \\
\hline public sector & $0.11 \%$ & 0.39 & $0.10 \%$ & 0.43 & $0.08 \%$ & 0.53 & $0.10 \%$ & 0.42 \\
\hline intermediate status group & $0.04 \%$ & 0.58 & $0.03 \%$ & 0.72 & $0.0003 \%$ & 1.00 & $0.04 \%$ & 0.58 \\
\hline high status group & $-0.07 \%$ & 0.52 & $-0.02 \%$ & 0.90 & $-0.13 \%$ & 0.36 & $0.05 \%$ & 0.74 \\
\hline Fraction with $\mathrm{dP} / \mathrm{d}$ (sweep-up) $>0$ & \multicolumn{2}{|c|}{0.01} & \multicolumn{2}{|l|}{0.71} & \multicolumn{2}{|l|}{0.59} & 1.00 & \\
\hline
\end{tabular}

All equations include time and sector dummies.

1) $\mathrm{H}_{0}$ : "coefficients jointly insignificant"

2) $\mathrm{H}_{0}$ : "homoskedasticity" (The heteroskedasticity equation contains the regressors wage level, wage sweep-up, and number of external job moves.) 


\section{Appendix}

Table A1: Estimation results of the wage rigidity model with uniform measurement errors (Model 2)

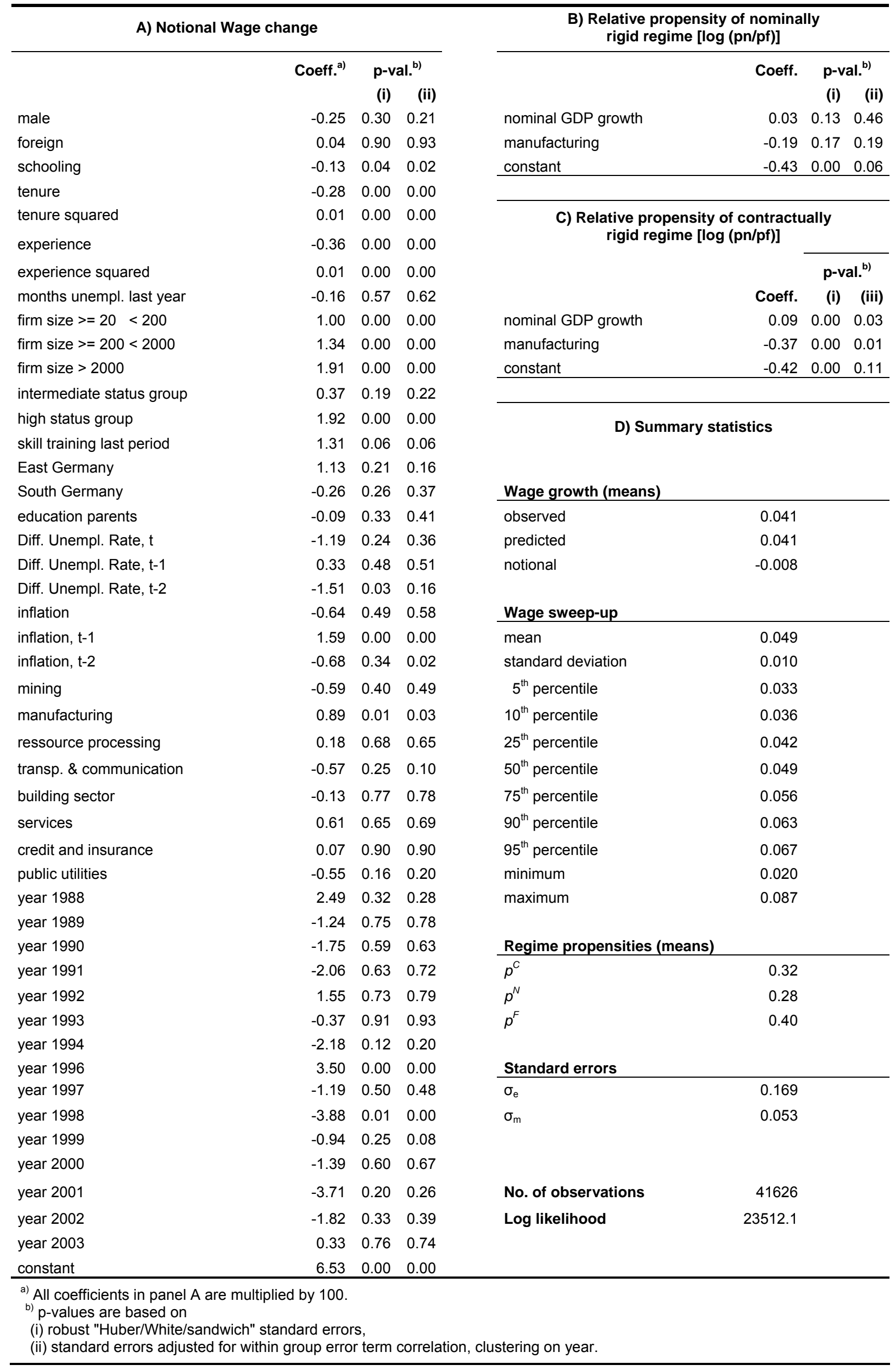


Table A2: Heteroskedastic probit regression of mobility in period $t+1$ based on wage sweep-up of the wage rigidity model 2

\begin{tabular}{|c|c|c|c|c|c|c|c|c|}
\hline & \multicolumn{2}{|c|}{ Quits } & \multicolumn{2}{|c|}{ Layoffs } & \multicolumn{2}{|c|}{ Promotions } & \multicolumn{2}{|c|}{ Transfers } \\
\hline No. of observations & \multicolumn{2}{|c|}{38328} & \multicolumn{2}{|c|}{38328} & \multicolumn{2}{|c|}{36764} & \multicolumn{2}{|c|}{36764} \\
\hline P-Val. Wald test of joint significance ${ }^{1)}$ & \multicolumn{2}{|c|}{0} & \multicolumn{2}{|c|}{0} & \multicolumn{2}{|c|}{0} & \multicolumn{2}{|c|}{0.000} \\
\hline P-Val. LR test of heteroskedasticity ${ }^{2)}$ & \multicolumn{2}{|c|}{0} & \multicolumn{2}{|l|}{0.07} & \multicolumn{2}{|c|}{0.003} & \multicolumn{2}{|c|}{0.09} \\
\hline Sample probability of $y=1$ & \multicolumn{2}{|c|}{$3.26 \%$} & \multicolumn{2}{|c|}{$2.98 \%$} & \multicolumn{2}{|c|}{$1.38 \%$} & \multicolumn{2}{|c|}{$0.66 \%$} \\
\hline Mean predicted probability of $y=1$ & \multicolumn{2}{|c|}{$3.26 \%$} & \multicolumn{2}{|c|}{$2.98 \%$} & \multicolumn{2}{|c|}{$1.38 \%$} & \multicolumn{2}{|c|}{$0.66 \%$} \\
\hline \multirow[t]{2}{*}{ Probability of $y=1$ predicted at means } & \multicolumn{2}{|c|}{$1.45 \%$} & \multicolumn{2}{|c|}{$1.60 \%$} & \multicolumn{2}{|c|}{$0.56 \%$} & \multicolumn{2}{|c|}{$0.36 \%$} \\
\hline & $\begin{array}{l}\mathrm{dP} / \mathrm{dX} \text { at } \\
\text { means }\end{array}$ & P-Val & $\begin{array}{l}\mathrm{dP} / \mathrm{dX} \text { at } \\
\text { means }\end{array}$ & P-Val & $\begin{array}{l}\mathrm{dP} / \mathrm{dX} \text { at } \\
\text { means }\end{array}$ & $\begin{array}{l}\text { P- } \\
\text { Val }\end{array}$ & $\begin{array}{l}\mathrm{dP} / \mathrm{dX} \text { at } \\
\text { means }\end{array}$ & $\begin{array}{l}\text { P- } \\
\text { Val }\end{array}$ \\
\hline wage sweep-up * 100 & $-1.11 \%$ & 0.00 & $-1.04 \%$ & 0.00 & $0.24 \%$ & 0.03 & $0.11 \%$ & 0.19 \\
\hline hourly wage level & $0.004 \%$ & 0.84 & $-0.10 \%$ & 0.00 & $-0.02 \%$ & 0.05 & $0.01 \%$ & 0.08 \\
\hline collectively bargained wage growth & $0.17 \%$ & 0.03 & $0.18 \%$ & 0.01 & $-0.07 \%$ & 0.08 & $-0.06 \%$ & 0.15 \\
\hline age & $0.17 \%$ & 0.01 & $-0.02 \%$ & 0.71 & $-0.06 \%$ & 0.00 & $-0.02 \%$ & 0.00 \\
\hline fulltime & $-0.54 \%$ & 0.02 & $0.04 \%$ & 0.84 & $0.12 \%$ & 0.35 & $0.14 \%$ & 0.09 \\
\hline East Germany & $-0.89 \%$ & 0.00 & $1.25 \%$ & 0.00 & $-0.02 \%$ & 0.88 & $0.15 \%$ & 0.20 \\
\hline foreign & $-0.47 \%$ & 0.00 & $0.51 \%$ & 0.01 & $-0.27 \%$ & 0.00 & $0.001 \%$ & 0.99 \\
\hline male & $0.31 \%$ & 0.01 & $0.25 \%$ & 0.07 & $-0.03 \%$ & 0.71 & $-0.16 \%$ & 0.03 \\
\hline schooling & $0.08 \%$ & 0.00 & $-0.04 \%$ & 0.25 & $0.10 \%$ & 0.00 & $0.06 \%$ & 0.00 \\
\hline number skill trainings & $0.01 \%$ & 0.89 & $-0.11 \%$ & 0.25 & $0.23 \%$ & 0.00 & $0.10 \%$ & 0.00 \\
\hline tenure & $-0.11 \%$ & 0.00 & $-0.02 \%$ & 0.08 & $0.02 \%$ & 0.02 & $0.01 \%$ & 0.14 \\
\hline firm size $>=20<200$ & $-0.82 \%$ & 0.00 & $-0.91 \%$ & 0.00 & $0.53 \%$ & 0.03 & $0.05 \%$ & 0.71 \\
\hline firm size $>=200<2000$ & $-1.05 \%$ & 0.00 & $-1.33 \%$ & 0.00 & $1.51 \%$ & 0.00 & $0.28 \%$ & 0.10 \\
\hline firm size $>2000$ & $-1.57 \%$ & 0.00 & $-1.79 \%$ & 0.00 & $2.08 \%$ & 0.00 & $0.75 \%$ & 0.00 \\
\hline number external moves & $-0.001 \%$ & 0.99 & $0.20 \%$ & 0.01 & $0.15 \%$ & 0.00 & $0.06 \%$ & 0.01 \\
\hline public sector & $-0.90 \%$ & 0.00 & $-1.21 \%$ & 0.00 & $0.10 \%$ & 0.42 & $0.09 \%$ & 0.45 \\
\hline intermediate status group & $-0.17 \%$ & 0.18 & $-0.50 \%$ & 0.00 & $0.13 \%$ & 0.15 & $0.04 \%$ & 0.60 \\
\hline high status group & $-0.68 \%$ & 0.00 & $-0.65 \%$ & 0.00 & $0.68 \%$ & 0.01 & $0.04 \%$ & 0.76 \\
\hline Fraction with $\mathrm{dP} / \mathrm{d}$ (sweep-up) $>0$ & \multicolumn{2}{|c|}{0.00} & \multicolumn{2}{|l|}{0.00} & 1.00 & & 0.99 & \\
\hline
\end{tabular}

All equations include time and sector dummies.

1) $\mathrm{H}_{0}$ : "coefficients jointly insignificant"

2) $\mathrm{H}_{0}$ : "homoskedasticity" (The heteroskedasticity equation contains the regressors wage level, wage sweep-up, and number of external job moves.) 